\title{
Bilateral pellucid marginal degeneration with oculocutaneous albinism
}

\author{
Amanjot Kaur, ${ }^{1}$ Kanakagiri Akhila, ${ }^{2}$ Srikant Kumar Sahu, ${ }^{1}$ Srikanta Kumar Padhy ${ }^{3}$
}

${ }^{1}$ Cornea and Anterior Segment, LV Prasad Eye Institute Bhubaneswar Campus, Bhubaneswar, India

${ }^{2}$ Comprehensive Ophthalmology, LV Prasad Eye Institute Bhubaneswar Campus, Bhubaneswar, India

${ }^{3}$ Vitreoretina, LV Prasad Eye Institute Bhubaneswar Campus, Bhubaneswar, India

\section{Correspondence to} Dr Srikanta Kumar Padhy; srikantkumar.padhy19@gmail. com

Accepted 1 June 2021
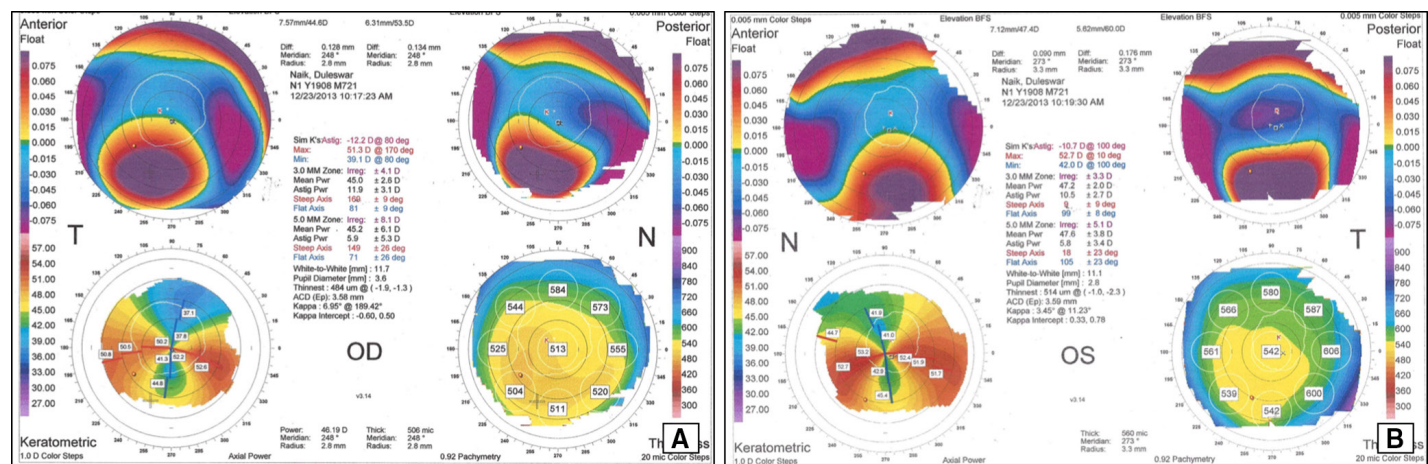

Figure 2 Orbscan of both eyes $(A, B)$ shows flattening of cornea in the vertical meridian, against the rule astigmatism, $3 \mathrm{~mm}$ and $5 \mathrm{~mm}$ zone difference outside normal limits ( $>1.5 \mathrm{D}$ and $>2 \mathrm{D}$, respectively), steeping in inferior part of cornea on both anterior and posterior float, crab claw appearance on keratometric map and thinnest pachymetry in inferior part of cornea (from 6 to 8 O' clock). OD, right eye; OS, left eye.

\section{DESCRIPTION}

A 54-years-old man, a known case of oculocutaneous albinism (OCA) type 1, presented to us with gradualonset diminution of vision both eyes (OU) for 5 years. The patient had no prior history of ocular trauma. There was no history of any systemic illness, especially collagen vascular disorder. The best-corrected visual acuity (BCVA) was counting fingers $1 \mathrm{~m}$ and $2 \mathrm{~m}$, with refraction of $-13 \mathrm{DS} /-2$ DC@110 and -14 DS in right (OD) and left eye (OS), respectively. Ocular examination revealed bilateral horizontal, jerky pendular nystagmus of moderate amplitude and frequency, with null at straight gaze. Slit-lamp examination revealed bilateral inferior band of corneal steeping with ectasia, hypopigmented iris with transillumination defects and cataractous lens (figure 1A,B).
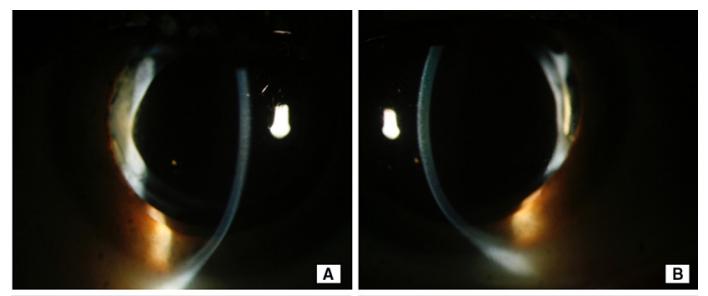

Check for updates

(C) BMJ Publishing Group Limited 2021. No commercial re-use. See rights and permissions. Published by BMJ.

To cite: Kaur A, Akhila K Sahu SK, et al. BMJ Case Rep 2021;14:e243640. doi:10.1136/bcr-2021243640
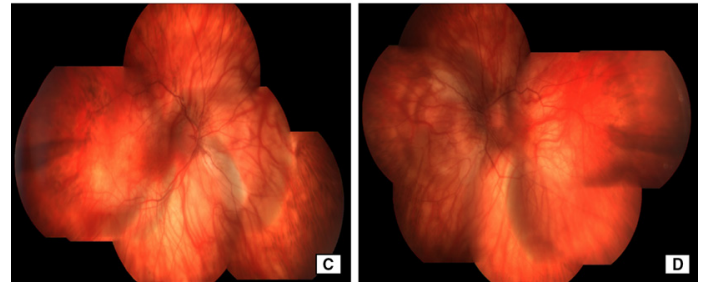

Figure 1 Slit-lamp picture of both eyes $(A, B)$ shows inferior corneal ectasia. Fundus photograph of both eyes (C, D) shows dull foveal reflex and hypopigmented fundus with prominent choroidal vessels.
Dilated fundus evaluation revealed hypopigmented fundus with prominent choroidal vessels and blunted foveal reflex OU (figure 1C,D). OU Orbscan (Bausch and Lomb) revealed against the rule astigmatism, inferior corneal steeping (anterior-posterior float), 'crab-claw' pattern (keratometric map) and inferior corneal thinning from 6 to 8 o'clock (figure $2 \mathrm{~A}, \mathrm{~B}$ ). Based on above findings, a diagnosis of OU pellucid marginal degeneration (PMCD) with OCA was made, was advised for cataract extraction along with intraocular lens implantation. His BCVA improved to 20/80 and 20/60 in OD and OS, respectively, and has remained stable at the last follow-up visit.

OCA is an autosomal recessive disorder of generalised hypopigmentation, with OCA I being the most severe form. ${ }^{1}$ Various ocular manifestations of OCA include photophobia, pendular jerky nystagmus, iris transillumination defects, foveal hypoplasia, abnormal

\section{Patient's perspective}

I am happy that my disease could be diagnosed at an early stage so as to be on routine follow-up and prevent future complications. I and my family members have been apprised about my condition, its natural course and possible complications.

\section{Learning points}

- Oculocutaneous albinism (OCA) can rarely be associated with pellucid marginal degeneration.

- Corneal ectatic disorders in the setting of OCA are more likely a consequence rather than independent association. 
decussation of optic nerve head fibres and strabismus. ${ }^{2}$ Though coexistence of OCA and keratoconus has been stated earlier ${ }^{3}$; to our knowledge the association between OCA and PMCD has never been reported in the literature. Prior studies in mice strains have documented the strong association of corneal thickness with skin pigmentation, therefore, corneal ectatic disorders in the setting of OCA are more likely a consequence rather than independent association. ${ }^{4}$ PMCD is a rare bilateral ectatic corneal disorder, involving inferior 4-8 o' clock in most of the cases, commonly discovered between 2 nd and 5 th decade. ${ }^{5}{ }^{6}$ Hallmark of PMCD on topography is zone of corneal thinning with obvious flattening of the cornea along the vertical meridian and 'against-the-rule' astigmatism. Characteristically 'crab-claw', 'butterfly' or 'kissing doves' in topography map also points towards PMCD, though not conclusively. ${ }^{7}$ The incumbent case highlights the unusual and extremely rare coexistence of bilateral PMCD with OCA.

Contributors AK and KA: data collection, writing manuscript. SKP and SKS: reviewing and conception of idea.
Funding This study was funded by Hyderabad Eye Research Foundation (LVPEI-243640-2021)

Competing interests None declared.

Patient consent for publication Obtained.

Provenance and peer review Not commissioned; externally peer reviewed.

\section{REFERENCES}

1 Grønskov K, Ek J, Brondum-Nielsen K. Oculocutaneous albinism. Orphanet J Rare Dis 2007;2:43.

2 Kirkwood BJ. Albinism and its implications with vision. Insight 2009:34:13-16.

3 Rao VA, Swathi P, et al, Chaitra. Bilateral keratoconus with oculocutaneous albinism. Indian J Dermatol Venereol Leprol 2008;74:407.

4 Dimasi DP, Hewitt AW, Kagame K, et al. Ethnic and mouse strain differences in central corneal thickness and association with pigmentation phenotype. PLoS One 2011:6:e22103.

5 Sridhar MS, Mahesh S, Bansal AK, et al. Pellucid marginal corneal degeneration. Ophthalmology 2004;111:1102-7.

6 Krachmer JH, Feder RS, Belin MW. Keratoconus and related noninflammatory corneal thinning disorders. Surv Ophthalmol 1984;28:293-322.

7 Gruenauer-Kloevekorn C, Fischer U, Kloevekorn-Norgall K, et al. Pellucid marginal corneal degeneration: evaluation of the corneal surface and contact lens fitting. $\mathrm{Br} J$ Ophthalmol 2006:90:318-23.

Copyright 2021 BMJ Publishing Group. All rights reserved. For permission to reuse any of this content visit

https://www.bmj.com/company/products-services/rights-and-licensing/permissions/

BMJ Case Report Fellows may re-use this article for personal use and teaching without any further permission.

Become a Fellow of BMJ Case Reports today and you can:

- Submit as many cases as you like

- Enjoy fast sympathetic peer review and rapid publication of accepted articles

- Access all the published articles

Re-use any of the published material for personal use and teaching without further permission

Customer Service

If you have any further queries about your subscription, please contact our customer services team on +44 (0) 2071111105 or via email at support@bmj.com.

Visit casereports.bmj.com for more articles like this and to become a Fellow 